\title{
IMPLANTAÇÃO DA AUTOMAÇÃO COMO FORMA DE MELHORIA NO PROCEDIMENTO OPERACIONAL PADRÃO (POP) EM UMA INDUSTRIA FRIGORÍFICA EM NOVA ANDRADINA - MS: UM ESTUDO DE CASO
}

\author{
Congresso Nacional Online de Empreendedorismo, 3ạ edição, de 06/12/2021 a 08/12/2021 \\ ISBN dos Anais: 978-65-81152-30-7
}

SANTOS; ROSENILDA SOUZA dOS ${ }^{1}$, PIOVESAN; Gleice Copede ${ }^{2}$, LEAL; Luciano ${ }^{3}$, OLIVEIRA; Maria Ester de ${ }^{4}$, COSTA; Renan da Silva ${ }^{5}$

\section{RESUMO}

A produção bovina no país brasileiro, ocupa uma posição destaque no ranking mundial no mercado nacional e internacional. Através disto, busca-se cada vez mais garantir a produtividade, e automaticamente a redução de custos com objetivos de maior rentabilidade para a cadeira produtiva, a qual envolve desde a produção dos animais até a comercialização de carcaças e sub produtos. Desta forma, através da necessidade de melhor garantir resultados, a principal busca em melhorias dos processos, inicia-se com a utilização da automação industrial dentro de indústrias frigorificas. A automação industrial, é uma atividade em constante crescimento, devido a sua grande escala de benefícios e vantagens que pode apresentar dentro do elo industrial, como melhorias em processos de produção, redução de custos operacionais principalmente a mão de obra, a qual ocupa percentagens significativas no custo de produção desta cadeia. Diante disto, a presente pesquisa traz como seu principal objetivo verificar se existe eficiência através da implementação da automação em um setor de miúdos de uma empresa frigorifica de miúdos, localizada no município de Nova Andradina - MS. A pesquisa garantiu análises entre os anos de 2016 á 2020, em números de rendimento na produção do mocotó. O método do trabalho adotado, foi quantitativo, qualitativo e exploratório, o qual compreendeuse o seu desenvolvimento dentro do ano de 2020. Através disto, foi possível concluir que o processo de automação industrial para o meio, mostrou-se benéfico através da utilização da máquina "Depiladora de mocotó" alocada dentro do setor de miúdos. O processo foi garantindo crescimento constante para o meio de produção quando comparado a anos anteriores, onde a através deste, já se obteve uma rentabilidade de 2,21\%, enquanto para $2016(0,40 \%) 2017$ (0,59\%) 2018 (0,72\%) e 2019 $(1,01 \%)$ respectivamente, indicando o crescimento constante da melhoria no processo da obtenção de peças de mocotó prontas para a comercialização.

PALAVRAS-CHAVE: Tecnologia, Automação, Produtividade, Resultado 